\title{
Marxism and anarchism in an age of neoliberal crisis
}

Simon Choat

School of Economics, History, and Politics, Kingston University, Penrhyn Road, Kingston upon Thames, Surrey KT1 2EE

\section{Abstract}

In the aftermath of the financial crisis that began in 2008 , various commentators have suggested that we are witnessing an 'anarchist turn': a revival of anarchist ideas and strategies exemplified by resistance movements such as Occupy. In the light of this revival, some have argued in favour of a 'left convergence': an alliance between anarchism and Marxism that can unite the radical left. Although it accepts that such alliances can have pragmatic efficacy, this article argues that these calls for convergence should be treated with caution. It challenges claims of a recent anarchist turn by claiming that neoliberalism itself has been the central beneficiary of a crisis to which the left has failed to respond effectively. Given this context of reversal and even defeat for the left, the article suggests that what is required today is a sober reflection on the relative merits of Marxism and anarchism. It sets out to establish what distinguishes Marxism from anarchism today and it argues that the former contains superior resources with which to challenge the current dominance of neoliberalism. In order to elucidate the strengths of Marxism, it addresses three common anarchist criticisms of Marxism concerning: its authoritarian strategies; its economic reductionism; and its lack of moral or ethical perspective. It argues that each of these criticisms inadvertently highlight the advantages of Marxism over anarchism. The aim of the article is not render anarchism obsolete but to respond to claims of an anarchist turn and subsequent calls for left convergence by highlighting the continuing vitality and strength of Marxism and raising questions for those who advocate an anarchist politics. 


\section{Introduction: A left convergence?}

In the wake of the financial crisis that began in 2007 , there have been a growing number of calls for convergence on the radical left. In particular, there have been appeals for a rapprochement or alliance between anarchism and Marxism (e.g. Kinna and Prichard 2012). These calls have a certain logic, given that both anarchism and Marxism appear especially well placed to address the neoliberal conditions that led to the crisis. The consequences of neoliberal globalisation have after all vindicated some of the central arguments of both ideologies: in The Communist Manifesto Marx and Engels presciently anticipated economic globalisation and its effects, while the dispersion of state sovereignty that it has produced has arguably validated claims that at least at a global level we already live in an anarchic world (Bottici 2013: 25). More importantly, both anarchism and Marxism have played highprofile roles in responding to the crisis: anarchist activists, ideas, and strategies have been central to resistance movements like Occupy (Graeber 2012, 2013), while Marxist political economy has proved invaluable in analysing events over which mainstream classical economics has only been able to maintain an embarrassed silence (Lapavitsas 2012, 2013).

On the other hand, however, it can be argued with equal plausibility that anarchism, Marxism, and the left in general have proved notably ineffective in responding to the crisis. Far from representing a revival, in Western Europe at least it is just as credible to claim that this is a moment of historic defeat for the left. If this has been a neoliberal crisis, it is not simply because it was caused by neoliberalism, nor because for a brief moment it seemed that the theories and logic of neoliberalism had been discredited and hence thrown into crisis. Rather, it is above all because neoliberal capitalism has emerged even stronger from the crisis that it caused: what is euphemistically named 'austerity' represents the 
consolidation and extension of the same neoliberal policies that produced the very problems (of recession, debt, and unemployment) that it is purported to solve.

So while in theory anarchism and Marxism are well placed to offer insights into our current predicament, in practice the conditions for any revival of the radical left are not necessarily propitious. As such, it is my argument that we should treat with caution calls for an alliance between anarchism and Marxism and instead engage in sober reflection on their relative strengths and weaknesses. Anarchists and Marxists find common cause in confronting the forms of exploitation and oppression generated by contemporary neoliberalism, and our everyday organisation and activism can only be strengthened by maintaining and extending existing alliances. But there is no contradiction in calling for solidarity in practice and using the tools of theory to investigate and sharpen distinctions. Indeed, any attempt to find 'common ground' must necessarily involve some assessment of the relative strengths and weaknesses of the two parties, as a prelude to the search for or negotiation of such common ground. Hence although I ultimately argue that Marxism offers superior resources for challenging neoliberalism, this claim does not in any way rule out a potential left convergence.

Even those calling for convergence implicitly acknowledge that anarchism and Marxism remain distinct: this article sets out to explore those distinctions in more detail. Recognising that both anarchism and Marxism are broad and varied movements, I nonetheless claim that it is both possible and desirable to identify important differences between each. I will argue that the recent crisis and its aftermath help to bring into sharper focus the differences between anarchism and Marxism - and, moreover, illuminate the advantages of the latter over the former in terms of helping us to understand and resist the dominance of neoliberalism. 
This argument is not made in the interests of doctrinal purity or petty political pointscoring, but as part of a pragmatic investigation into the opportunities for resistance under current conditions. Moreover, rather than initiating a Marxist offensive against anarchism, my argument here is to a great extent reactive or defensive: it is made to counter and moderate claims that radical politics over the past decade has experienced an 'anarchist turn' (Critchley 2013), that we are witnessing a 'new anarchism' (Graeber 2007) or 'neoanarchism' (Castells 2005), or even that 'we are all anarchists now' (Carter and Morland 2004). Very often these celebratory claims are made at the expense of Marxism, as a resurgent and rejuvenated anarchism is contrasted with an outmoded and exhausted Marxism. What follows, therefore, is as much a defence of Marxism as it is a critique of anarchism. While it is indisputable that many radical activists today identify as anarchists, many do not, and I maintain that there are flaws in anarchist approaches to politics.

In order to draw out the strengths of Marxism, I will address three of the most common criticisms of Marxism made by anarchists, and in so doing attempt to develop a definition of Marxism that is restrictive enough to distinguish it from anarchism yet capacious enough to incorporate its many varieties. Those criticisms are that, first, Marxism favours authoritarian forms of organisation, and that this authoritarianism is rooted in theoretical flaws. Secondly, that Marxism is economically reductive, unable in particular to account for the specific threats posed by the power of the state. Thirdly and finally, that Marxism lacks a moral theory and hence its economic critique requires an ethical supplement. I will argue that each of these criticisms unintentionally highlights the advantages of Marxism over anarchism. In making my argument I will respond to recent anarchist texts, avoiding as much as possible the disputes of the 'classical' period, such as those between Marx and Proudhon or Bakunin, or as took place around the 1917 
revolution. This is for a number of reasons. First, those disputes are already well known enough and do not need to be rehearsed here. ${ }^{1}$ Second, while those disputes have enormous historical importance, and the terms in which they were undertaken remain influential, there is a danger that in focusing on them we obscure what is distinctive about and most relevant to contemporary radical politics, replicating yesterday's polemics rather than illuminating today's disagreements. Finally, anarchism is if anything much broader than Marxism, and hence any characterisation of anarchism and its critique of Marxism will necessarily be selective: focusing only on recent anarchist works is one, relatively uncontroversial, way of narrowing the criteria of definition. The presentations of Marxism and anarchism that follow will of course be open to dispute, but that is true of all attempts to determine any large, diverse, and living body of political thought and practice.

\section{Strategy and organisation}

The most common way to distinguish anarchism from Marxism is to claim that while they share a mutual aim - a stateless and classless society - they diverge in their proposed means to that end. Anarchists reject the consequentialist claim that the end justifies the means and instead insist on a prefigurative politics in which the means prefigure the end: because they look to a non-hierarchical and decentralised future, they support nonhierarchical and decentralised strategies in the present (Franks 2012: 216, 220; Shannon et al 2012: 32; Schmidt and van der Walt 2009: 65). This difference is often framed in terms of strategy, as in the recent debate between the syndicalist anarchist Lucien van der Walt and the Marxist-Leninist Paul Blackledge, in which the issue of the state and the associated questions of political organisation and leadership came to the fore (Blackledge 2010; van

\footnotetext{
${ }^{1}$ For an overview of Marx's relationship to anarchism, see the classic study by Thomas 2010.
} 
der Walt 2011; Blackledge 2011). In practice the anarchist position entails support for tactics such as direct action and the rejection of antidemocratic forms of organisation in favour of autonomous and polycentric networks of activists (Gordon 2008: 34-40, 14-17; Graeber 2007). Because the state is viewed as an authoritarian body, they reject any engagement with the state, from participation in parliamentary elections to the revolutionary seizure of the state apparatus. This is often formulated as a rejection of politics per se: political parties in particular are viewed as elitist, autocratic, and likely to lead to the reformist co-option of radical goals (Kinna 2009: 161).

Marxism - especially in its Leninist forms - is in contrast viewed by anarchists as authoritarian in its promotion of a vanguard party and a dictatorship of the proletariat. The dangers of such an approach have for anarchists been confirmed by the experiences of Marxist regimes in the $20^{\text {th }}$ century: 'all Marxist regimes ended as state capitalist dictatorships' (van der Walt 2011). For anarchists this is not merely a contingent dispute over choice of tactics, because they argue that the practical deficiencies in Marxism that they identify are rooted in theoretical weaknesses, two of which in particular are significant. First, by viewing the state merely as the instrument of the ruling class, Marxism does not recognise that the state is itself an autonomous source of power and so is always a threat to freedom, even if it is controlled by the working class or their representatives. Second, because it privileges a single site of oppression - i.e. capitalist relations of production - it also privileges a single agent of change, namely the industrial proletariat, who must necessarily be led by a vanguard leadership of intellectuals whose task is to interpret and analyse that oppression and who thereby disable the potential for bottom-up emancipation (Newman 2010: 81-86). 
It can hardly be denied that some forms of Marxism have been violently and disastrously authoritarian in practice. But this historical fact does not indicate a fundamental flaw within Marxism. In the first place, and as some anarchists recognise (Franks 2012), Marxism is not inherently authoritarian and contemporary Marxism certainly cannot be reduced to Leninism. ${ }^{2}$ There is a diversity of tactics and organisational forms within both anarchism and Marxism: neither can be defined or condemned according to their practical strategies. Like anarchists, Marxists such as John Holloway (2010) and Michael Hardt and Antonio Negri (2006) have advocated 'networked' and 'horizontal' forms of organisation that reject or seek to limit centralised and 'vertical' hierarchies. The point here is not that all Marxists are in agreement with Holloway or Hardt and Negri, nor that they represent a more 'authentic' or compelling form of Marxism than Leninism: the point is simply that the anarchist critique of Marxism's authoritarianism is called into question by the existence of self-identified Marxists who advocate explicitly non-authoritarian modes of organisation. Moreover, such figures are only the latest in a long-standing line of libertarian Marxists, from Luxemburg via Marcuse and Guérin and even including some of Lenin's work (The State and Revolution was anti-authoritarian enough to be praised by Lenin's anarchist contemporaries [Birchall 2010]). By invoking the threatening spectre of the dictatorship of the proletariat, anarchists are not only reviving debates whose relevance is doubtful when applied to our own political, economic, and social conditions, they are also failing to recognise or acknowledge the diversity of Marxism.

Notwithstanding this strategic plurality within Marxism, it is anyway questionable whether a particular form of organisation can be defined as intrinsically progressive. Given

\footnotetext{
${ }^{2}$ Though even where the existence of other traditions in Marxism is recognised by anarchists, the conclusion is often that 'the predominant element' of Marxism remains nonetheless 'overwhelmingly authoritarian' (Schmidt and van der Walt 2009: 24).
} 
that both the US army and its enemies such as al-Qaeda, for example, are increasingly adopting polycentric, networked forms (albeit in combination with traditional vertical hierarchies), it is clear that such forms do not always produce a radical politics. Ultimately, what really distinguishes emancipatory from reactionary groups are not their strategies or organisational arrangements but the goals that they pursue (Hardt and Negri 2006: 54-62, $93,218)$. The risk of anarchism's preoccupation with prefigurative politics is that is fetishises tactical purity at the expense of political analysis and aims.

Above all, the anarchist critique of Marxist strategies is premised on an overly simplistic understanding of the relationship between theory and practice. Anarchists have attempted to attribute Marxism's supposed antidemocratic tactics to its theoretical claims, but there can never be any straightforward connection between theoretical arguments and organisational or strategic practices. The links between theory and practice are complex and subtle and it is dangerous to read back from the practical failures of a movement in order to criticise a set of concepts and theories. To claim, for example, that Stalinism can be explained by mistakes in Marx's methodology, or even that the former throws doubt on the latter, is to risk the idealist and ultimately untenable argument that political or economic failures are produced by incorrect or adequate theory. Historical events can never simply disprove or discredit any ideological position, because ideas are always developed and applied within a variety of social and historical contexts. The gulag does not result from something that Marx wrote, but from a complex web of material causes. Anarchists in particular should be especially wary of attempting to discredit Marxism in this way, because practical experiments in anarchism have so seldom been successful: if we are to judge an ideology or movement by its operation 'in practice', then anarchism does not fare much better than Marxism (Choat 2013: 337-8). It may be that Leninist tactics have not achieved a 
classless and stateless society, but so far neither have anarchist tactics: anarchists may have cleaner hands than Marxists, but that is only because anarchists have had their hands on so little.

The anarchist critique of Marxist organisational forms is unconvincing, then, because it does not acknowledge the diversity of Marxist approaches and it tends towards a theoreticism that sees a linear, causal, and continuous line from theory to practice. Nonetheless, there are significant differences of strategy between anarchism and Marxism: it is just that these are less to do with organisation as such, and are much more broadly to do with differing attitudes toward politics and the state. Although some (though by no means all) anarchists have supported formal political organisations, with rules, membership criteria, and even internal discipline (Schmidt and van der Walt 2009: 247-263), they have traditionally rejected any engagement with the state - whether it be voting, demanding legal rights or protections, forming political parties, or attempting the revolutionary seizure of government - on the basis that such engagement can only end up replicating the oppressive hierarchies that they are fighting: either it will lead to new forms of dictatorship and bureaucracy (such as developed in the Soviet Union); or it will lead to parliamentary reformism and hence merely reinforce existing structures and relations of power.

If Marxists support (qualified) engagement with the state and even the formation of political parties, however, it is not because they think that centralised hierarchies are desirable or inevitable, but because they begin from a different understanding of politics. They argue that the anarchist abstention from state politics denies us the most effective means of political action: we disempower ourselves rather than the state when we refuse to engage with it. Making demands on the state does not necessarily entail an endorsement of the state, any more than the demands that are made by employees during a strike are an 
endorsement of the employer or of the system of wage-labour (Marx 1988). Anarchists themselves have at least implicitly recognised the efficacy of political engagement by occasionally supporting the policies of certain governments and even participating in elections (Engels 1988; Franks 2012: 216).

More than this, abstention from state politics is not a genuine option: whether we like it or not, we are all already involved in state politics, because we are all always already submitted to state power, control, and oppression. Anarchists are concerned that participation in conventional politics will lead to parliamentary reformism. But this concern is itself ultimately premised on a tacit acceptance of the liberal-parliamentary understanding of politics: to claim that we can safely repudiate state politics simply by refusing ever to enter a polling booth is to assume that 'the state' stops at the door of Parliament. Marxists, in contrast, have argued that the state apparatus includes educational institutions, the media, churches, the family, and so on (e.g. Althusser 1971): simply in going about our daily lives we are all therefore implicated in state politics. Given our necessary involvement within politics, the question is not whether we engage with it, but how we do so; even libertarian Marxists like Holloway argue that engagement with the state is inevitable (Holloway 2005: 40). In contrast, the anarchist recommendation of disengagement from the state risks a politics of withdrawal and isolation.

There are two related reasons why under our current conditions in particular the Marxist willingness to engage in state politics is preferable to an anarchist position. The first is the dominance of neoliberalism today. Given the strength of neoliberalism since the crisis that it created, there is a strong case for a certain pragmatism in our response. A danger of the prefigurative politics favoured by anarchists is that it dogmatically dictates an a priori exclusion of certain forms of political action. For Marxists, on the other hand, political 
strategies must be decided according to particular conditions and within a certain context. In a context in which private companies are increasingly undertaking tasks previously performed by the state, the active defence of state services and institutions can be viewed as a radical position to adopt: defending welfare provision, public pensions, universal healthcare, and free higher education should be seen not as a reformist compromise with the existing order but as safeguarding the gains of class struggle against capitalist processes of accumulation by dispossession.

This leads to the second reason for doubting the refusal of state politics as a viable tactic under current conditions, which concerns the specific role of the state under neoliberalism. The anti-state politics of anarchism may have made sense during eras in which the state could plausibly be presented as the main threat to freedom and equality: during the period of nation-building and imperialistic expansion in the mid- to late-19th century, of the rise of fascism in the early-20th century, or even of the development of welfare capitalism after WWII. But it has far less purchase in an era in which neoliberalism, as both the official ideology and a form of everyday common sense, is anti-statist. Put simply, the attack on state power too easily echoes the rhetoric of neoliberalism itself (Taylor 2013: 735). When government actors themselves are explicitly endorsing the retreat of the state, then anarchist attacks on state power have limited efficacy either as a tactical call to arms or as a convincing analysis of our present conjuncture. In practice, of course, it is true that neoliberalism has not dissolved state power. But nor has the relation between state and capital remained the same under neoliberalism, such that our analyses, strategies, or rhetoric need not alter. The nature of this relationship between state and capital will be examined in the next section. 


\section{Economics and class}

As we have seen, anarchists have very often linked Marxism's supposed strategic weaknesses to an alleged economic reductionism. The argument is that if Marxists erroneously believe that radical change can be effected through the state, it is in large part because they do not understand that the state is itself a specific and autonomous source of power and hence is a threat to freedom in its own right. Viewing it as nothing more than an instrument of the ruling class, Marxists have failed to grasp that the state has its own history, development, and techniques of domination (Newman 2010: 77-78). The root cause of this problem according to anarchists is Marxism's belief that 'power as such is reducible to economic power', meaning that all oppression is interpreted as class oppression (Jun 2012: 102, 96). This obscures other forms and sites of domination, or at best means that they are accounted for only by subsuming them within an economic analysis (so that, for example, power relations within the family are interpreted only insofar as they contribute to capitalist relations of production). 'Anarchism, on the other hand, is a critique of domination that typically is not reducible to economics.... Anarchists tend to see forms of domination presenting themselves in society without the need to root them in the economy' (Shannon et al 2012: 15). Hence although class may be central to the social analyses of many anarchists, class is understood by anarchists as a political relation of domination as well as an economic relation of production (Schmidt and van der Walt 2009: 109). For anarchists, in other words, it is only by moving beyond a narrow focus on economics that we can understand our oppression and develop the conditions of our own emancipation.

How Marxists respond to these charges depends on how they are framed and interpreted. Sometimes the accusation is that Marxism is economistic, i.e. that it proposes that all historical phenomena can be explained as products of an always-determinant 
economic base. If it were true, then this charge would certainly undermine Marxism's validity. But very few Marxists have actually endorsed this kind of economism in which Marxism is supposed to be a master key that can unlock every single aspect of human history. Certainly Marx himself was more circumspect, presenting his work as a theory of the origins and development of the capitalist mode of production in Western Europe whose wider applicability was yet to be established (Marx and Engels 1956: 379). In the same way that Marxism is not inherently authoritarian (evidenced by the broad range of organisational strategies advocated by different Marxists), nor is it inherently economistic.

Often, however, the anarchist critique is not specifically that Marxism is economistic, but rather that it focuses too narrowly on economics, to the exclusion of other forms of power and oppression. Some commentators have responded to this charge by denying that the scope of Marxism's analysis is narrow, arguing that class struggle is as much as a social, political, and cultural issue as it is an economic one, and that Marx's concepts of production and labour are anyway far more capacious than most (Eagleton 2011: 119-127). However, rather than denying that Marxism focuses on economics, I will argue that this focus is a key strength of Marxism, and is especially pertinent and fruitful under our current neoliberal conditions. Neoliberalism precisely 'entails a very specific extension of the economy across of all of society' (Read 2009: 32) - a situation which is best analysed and resisted by a theory and movement that begins from and always prioritises economics. To argue, as anarchists do, that we need to move beyond or outside economics is to misunderstand the specific novelty of neoliberalism.

It is widely agreed that what distinguishes neoliberalism as both a theory and a practice is not the withdrawal of the state from the market but the extension of the market into new domains (Brown 2006; Mirowski 2013; Dardot and Laval 2014; Harvey 2007): it 
establishes 'a general regulation of society by the market' (Foucault 2010: 145). As services are privatised, goods and institutions marketised, and relationships commodified, the economic logic of the market comes to dominate every aspect of our lives and behaviour. This dominance is reflected in the increasing imperialism of the discipline of economics: the rational-choice reasoning of neoliberal economists such as Gary Becker are recycled in popular form (e.g. Harford 2008; Levitt and Dubner 2006), as we are urged always to see ourselves as rational economic actors maximising benefits and minimising costs within a market environment, whether we are buying a car or looking for a husband.

It could be argued that the predominance of this neoliberal logic is precisely why we need to move beyond economics, as anarchists demand: to resist neoliberalism's attempt to interpret all human life in economic terms by showing that there are other, non-economic values, relationships, and forms of thought. ${ }^{3}$ But this would be to misidentify the operation of neoliberalism, underestimating the extent to which under neoliberalism all our relations and activities really have become economic. What neoliberalism effects is not merely an 'ideological' shift in which people are encouraged to accept certain market-friendly beliefs or values, or whereby the theoretical norms of neoliberal economics are imposed upon new fields: regardless of our beliefs, we are forced to behave as rational economic actors. Under neoliberalism, Becker's homo economicus is not an ideological fantasy but a material reality. Moreover, its scope and impact is such that under neoliberalism 'economics is coextensive with all of society' (Read 2009: 28). As such, it is futile to argue that resistance can take the form of fostering 'relationships that cannot be subsumed under neoliberalism' as 'alternative form[s] of social interaction' (May 2013: 66, 72): such a position not only risks

\footnotetext{
${ }^{3}$ Such an approach is advocated by liberals and communitarians (e.g. Anderson 1993; Sandel 2012) as well as by anarchists (e.g. May 2013).
} 
the isolationism criticised above, it also fails to recognise that neoliberalism has given us a society in which '[t]here is no longer an outside to capital' (Hardt and Negri 2006: 101-2). Rather than searching for a non-existent outside, Marxist thinkers have analysed the ways in which our entire social world is increasingly subsumed under capitalism, such that 'all activities are productive' (Negri 1989: 204): even formally non-capitalist activities are harnessed to produce and appropriate surplus value or to reproduce capitalist social relations. Although this subsumption has sometimes been referred to as 'extra-economic accumulation' (e.g. Glassman 2006: 617), it is perhaps more accurate to identify it as the economization of social life: the penetration of social life as a whole by capitalist relations of production. While this does not necessarily mean that all forms of oppression and conflict today are directly economic, it is plausible to claim that all oppression and conflict is today refracted through economics and cannot be explained or resisted without some form economic analysis. At the very least, given neoliberalism's economization of our social life, it seems like poor timing to complain that Marxism focuses too much on economics.

The fundamental significance of economic analysis, and the prudence of prioritising economics in the way that Marxism does, is reinforced if we consider the role of the state under neoliberalism. The neoliberal state is of course needed to protect and defend the appropriate legal and institutional framework for the development and flourishing of the market (Harvey 2007: 2). But more than this, the state under neoliberalism is itself 'marketised', with the introduction of a 'business model of the state' (Munck 2005: 63; Brown 2006: 698). This means, first, that the entire legitimacy of the state and its actions rests on 'its ability to sustain and foster the market' (Brown 2005: 41). Second, government policies and performance are themselves evaluated according to the economic criteria of efficiency and profitability (Foucault 2010: 246-247), with democracy now understood in 
market terms, such that citizens become 'consumers' of state services (Mirowski 2013: 5758). Finally, the state must both promote neoliberalism on the global stage and compete with other states on that stage for business investment (Munck 2005: 63).

In other words the domination of the state by the economy is no longer a Marxist fallacy but a real and ongoing process that is increasingly hard to deny - not least because in their promises to create 'business-friendly' environments, state actors themselves explicitly embrace their role as agents of capital. As Jacques Rancière has said: 'Marx's once scandalous thesis that governments are simple business agents for international capital is today an obvious fact...; it is the openly declared truth by which our governments acquire legitimacy' (Rancière 1999: 113). By insisting on non- or extra-economic analyses and on the autonomy of the state from the power of capital, anarchists risk missing the significance of the transformations that neoliberalism has effected.

\section{Morality and ethics}

Broadly speaking, many and maybe even most anarchists do in fact accept the fundamental concepts and claims of Marxian political economy, 'a theory of unprecedented and stillunmatched analytic power' (Schmidt and van der Walt 2009: 87; Price 2013: 5). ${ }^{4}$ However, as we have just seen, they object to what they see as the illegitimate extension of this political economy, an extension which they argue obscures other forms of repression and struggle. In addition, they claim that even within its appropriate limits any critique of political economy needs supplementing with moral claims about the injustice of capitalism

\footnotetext{
${ }^{4}$ Schmidt and van der Walt's praise for Marx's political economy, and their often accurate summary of its central points, is unfortunately undermined by their contention that Marx and Marxists believe that in a post-capitalist society goods will be distributed according to work via a market rather than according to need (Schmidt and van der Walt 2009: 88-89). A quick glance of the Critique of the Gotha Programme would disabuse the authors of this notion.
} 
(Jun 2010: 63). It is this second point which will be the focus of this final section of the article. The contrast here proposed by anarchists is not between an economically reductive Marxism and an anarchism that recognises the plurality of power relations, but between anarchism as a 'moral conviction, an ethical disposition' (Critchley 2013: 4) and a Marxism that obliterates ethical analysis. The argument offered is that 'what is most compelling about anarchism is its emphasis on ethics as a binding factor in political practice, as opposed to the silence or hostility to ethics that one finds in Marx and in many Marxist and postMarxist thinkers' (Critchley 2007: 93). Although it is acknowledged that there are some anarchists who share the Marxist suspicion or rejection of moral thought, these are treated as 'peripheral' to the anarchist tradition (Franks 2010: 2). Marxism, according to this perspective, dismisses morality as mere ideology or bourgeois prejudice. In the words of Engels, 'morality has always been class morality': reflecting the economic conditions from which it arose, it either justifies class rule, or is at best an empty expression of anger (Engels 1987: 87, 84). By repudiating morality in this way, anarchists claim, Marxism leaves itself without the resources to: adequately criticise the unfairness and injustices of the status quo; understand the ethical import of different strategies for change; formulate a moral vision of an alternative future. These flaws can for anarchists be traced back to Marx himself: 'Nowhere in his work did [Marx] ever suggest that people should be for socialism, that it was morally right to fight for it, or that ethics were a necessary component for a vision of a good society' (Price 2013: 123).

Despite Marx and Engels' explicit rejection of moral discourse and argumentation (e.g. Marx and Engels 1976: 247), some Marxists have responded to accusations of 
amoralism by attempting to develop a Marxist ethics. ${ }^{5}$ Those attempts themselves suggest that any effort to portray Marxism as straightforwardly hostile to ethics overlooks the diversity of Marxist perspectives on morality. However, rather than embracing Marxist ethics I will argue that Marxism is at its most distinctive and strongest when it dispenses with morality. I will focus on elucidating a Marxist critique of morality rather than trying to refute those Marxists who have argued in defence of morality, but it is at least worth noting here that Marxist defenders of morality have tended to proceed not so much by trying to develop a distinctive Marxist ethics as simply importing into Marxism the methods and conclusions of mainstream ethical theory, whether Kantianism (e.g. in Bernstein and Kautsky), virtue ethics (in the early Alasdair Maclntyre), or Rawlsian liberalism (in the works of analytical Marxists such as G. A. Cohen). As such, it is perhaps unsurprising that many Marxist ethicists eventually arrive at positions that are non- or even anti-Marxist.

Despite his stated intentions as a defender of Marxist ethics, Paul Blackledge's recent work offers some valuable insights into the relationship between Marxism and morality. As he notes, by addressing the social conditions within which moral theories developed, Marxism can explain both the content of specific moral theories (e.g. the persistent individualism of liberal moral theory) and the apparently irresolvable debates between competing and incommensurable theories (debates which reflect the fragmentation and competition characteristic of modern capitalist society) (Blackledge 2008). Blackledge goes on to claim that Marxism develops its own, alternative ethical perspective, rooted in the concrete struggles of the working class: those struggles both provide a moral standpoint from which capitalist exploitation can be condemned, and

\footnotetext{
${ }^{5}$ See for example the essays in Wilde 2001.
} 
promote the moral virtues of solidarity as an alternative to the amoral competitive individualism of capitalism (Blackledge 2012a, 2012b)

But although the contention that working-class struggles provide both a perspective from which to assess capitalism and a model for its supersession is persuasive, it is not clear what is gained from translating this contention into moral terms. Like some other Marxists, and like nearly all anarchists, Blackledge seems concerned that without ethical foundations we will be unable to engage in critique, as if the alternative to ethical critique must be a naïve faith in Marxism as a normatively neutral, purely descriptive or objective 'science', or as a mechanistic philosophy which presents the decline of capitalism as a natural inevitability without regard for its ethical desirability. But the struggles that Blackledge refers to are motivated by all kinds of reasons, because people have all kinds of reasons for wanting to resist capitalism: environmental destruction, low wages, poor working conditions, unemployment, expropriation of land, the production and reinforcement of forms of hierarchy and discrimination, etc. From these multifarious concrete grievances, an analytical abstraction is needed in order to demonstrate their common cause in the capitalist mode of production, but there is no need for a moral abstraction in which they are all united under a common name of Injustice or Inequality or Unfreedom. In other words, people do not need to be given reasons why they 'should' be against capitalism and for socialism: our task is not an ethical one of establishing the moral foundations of resistance, but a political one of organising, aiding, or articulating resistance.

A sophisticated Marxist critique of moral thought has been put forward by Fredric Jameson, for whom ethics is the supreme example of ideological thought. By this he means that it helps legitimate existing structures of power, but not in the usual sense that it is simply determined by its economic conditions, or is merely used to obscure class relations. 
Rather than its origins or content, it is the specific form of ethical thought that is ideological for Jameson. Ethics is always dualistic, because ultimately it always reduces everything to a question of good against evil - even if these fundamental categories are expressed in a variety of alternative dualisms, such as progressive against reactionary, or active against passive. Dualism according to Jameson (2009: 198) is 'the strong form of ideology as such' because it divides and condemns in this way, 'call[ing] for judgement where none is appropriate'. Such judgement relies either on the postulation of some transcendental position above or outside of what is being judged (and whose transcendental position is itself never fully justified), or on individualistic attempts to separate ourselves from what is Other and therefore evil: 'what is good is what belongs to me, what is bad is what belongs to the Other' (Jameson 1989: 234).

The dualisms of morality thus efface the central insight of dialectical thought, which is that something can be one thing and its opposite at the same time. Seen dialectically, capitalism is neither 'good' nor 'evil', neither (wholly) progressive nor (wholly) reactionary: it is rather a 'unity of opposites' in which 'progress produces genuine misery, and wealth unspeakable destitution' and 'whose evolution is (dialectically) at one with its breakdown, its expansion at one with its malfunction, its growth with its collapse' (Jameson 2011: 56, 142). From this perspective, what is required is an assessment of the forces and tendencies within capitalism, in order not to judge and condemn but to identify real possibilities for radical transformation. In this sense, the 'anti-capitalism' of the anarchist movement is facile and even ideological (in the pejorative sense of this word): it condemns without explaining, judges without analysing.

Beyond this general critique of moral theory, there are in addition specific pragmatic reasons why moral theory is unhelpful under current conditions. Formulating criticisms of 
the status quo in moral terms - as in demands for a more ethical world or way of life - are simply ineffective against a dominant neoliberalism. This is in part because such demands are too easily recuperated: one can criticise capitalism for its unethical practices, but such criticisms are today annulled by their absorption into newly commodified practices of 'ethical consumption' (Taylor 2013). But more than this, ethical critique presumes that there is a potential audience that will be receptive to moral claims, or at least a space in which such claims can be developed and heard. The problem is not that neoliberal capitalism has annihilated all moral values, drowned 'in the icy water of egotistical calculation', but rather that it has colonised all moral ground by redefining morality as egotistical calculation, 'configuring morality entirely as a matter of rational deliberation about costs, benefits, and consequences' (Brown 2005: 42). Under such circumstances, it is better to abandon moral critique altogether.

\section{Conclusions}

The three anarchist criticisms of Marxism that I have identified dovetail neatly with each other: Marxism uses authoritarian and state-based strategies in large part because it is economically reductive, unable to conceive of the state as an autonomous source of domination; its preoccupation with economics marginalises and even annihilates any ethical dimension to its critique; and its lack of moral perspective allows it to justify any actions and strategies, including the most authoritarian, in pursuit of its aims. Yet the potential Marxist responses to these criticisms that I have tried to outline also fit together, linked by anarchism's failure fully to come to terms with the changes that neoliberalism has effected: anarchism's refusal of state politics misunderstands both the rhetoric and reality of neoliberalism today; its attacks on economic reductionism fails to account for the 
economization of social life in a marketised society; and its endorsement of ethics is misplaced given the ineffectuality of moral critique against neoliberalism. These criticisms do not - and are not meant to - render anarchism obsolete, but they should bring into question the much-trumpeted 'anarchist turn'. To claim that 'we are all anarchists now' is either to try to marginalise Marxism or to deny the existence of significant distinctions on the radical left, whereas this article has maintained that important distinctions do remain: Marxism can be characterised in contrast to anarchism by its willingness to engage with the state, its foregrounding of political economy, and its rejection of moral theory and rhetoric. This characterisation is of course open to contestation, including and perhaps especially by other Marxists, but that is true of any attempt to delimit a political theory or movement. My aim has also been to show that Marxism is better suited than anarchism for addressing our current conjuncture, but this claim does not rule out a possible 'left convergence'. To the contrary, a frank assessment of the differences between anarchism and Marxism, and of their relative strengths and weaknesses, is a necessary and preliminary condition for any such convergence. 


\section{$\underline{\text { References }}$}

Althusser L (1971) Ideology and Ideological State Apparatuses (Notes towards an Investigation). In Lenin and Philosophy and other essays, trans. Brewster B. London: NLB.

Anderson E (1993) Value in Ethics and Economics. Cambridge, MA: Harvard University Press.

Birchall I (2010) Another side of anarchism. International Socialism Journal 127 http://www.isj.org.uk/?id=663, accessed 7 January 2015.

Blackledge P (2008) Marxism and ethics. International Socialism Journal 120 http://www.isj.org.uk/?id=486, accessed 7 January 2015.

Blackledge P (2010) Marxism and anarchism. International Socialism Journal 125 http://www.isj.org.uk/www.isj.org.uk/index6e0a.html?id=616\#125blackledge_2, accessed 31 March 2015

Blackledge $\mathrm{P}$ (2011) Anarchism, syndicalism and strategy: A reply to Lucien van der Walt. International Socialism Journal 131

http://www.isj.org.uk/www.isj.org.uk/index3074.html?id=746\&issue=131, accessed 31 March 2015

Blackledge P (2012a) Anarchism, Ethics, and Strategy. Critique 40(4): 595-603.

Blackledge P (2012b) Marxism and Ethics: Freedom, Desire, and Revolution. Albany, NY: State University of New York Press.

Bottici C (2013) Black and red: the freedom of equals. In Blumenfled J, Bottici C, Critchley S (eds.) The Anarchist Turn. London: Pluto Press.

Brown W (2005) Edgework: Critical Essays on Knowledge and Politics. Princeton, NJ: Princeton University Press.

Brown W (2006) American Nightmare: Neoliberalism, Neoconservatism, and DeDemocratization. Political Theory 34(6): 690-714.

Carter J, Morland D (2004) Anti-capitalism: Are we all anarchists now? In Carter J, Morland D (eds.) Anti-Capitalist Britain. Cheltenham: New Clarion Press.

Castells M (2005) Neo-Anarchism. La Vanguardia. 21 May.

Choat S (2013) Politics, power and the state: a Marxist response to postanarchism. Journal of Political Ideologies 18(3): 328-347.

Critchley S (2007) Infinitely Demanding: Ethics of commitment, politics of resistance. London: Verso. 
Critchley S (2013) Introduction. In Blumenfled J, Bottici C, Critchley S (eds.) The Anarchist Turn. London: Pluto Press.

Dardot P, Laval C (2014) The New Way of the World: On Neoliberal Society, trans. Elliott G. London: Verso.

Eagleton T (2011) Why Marx Was Right. New Haven, CT: Yale University Press.

Engels F (1987) Anti-Dühring. In Marx K, Engels F Collected Works, vol. 25. London: Lawrence and Wishart.

Engels F (1988) The Bakuninists at Work: An Account of the Spanish Revolt in the Summer of 1873. In Marx K, Engels F Collected Works, vol. 23. London: Lawrence and Wishart.

Foucault M (2010) The Birth of Biopolitics: Lectures at the Collège de France, 1978-79, ed. Senellart M, trans. Burchell G. Basingstoke: Palgrave Macmillan.

Franks B (2010) Introduction: Anarchism and Moral Philosophy. In Franks B, Wilson M (eds.) Anarchism and Moral Philosophy. Basingstoke: Palgrave Macmillan.

Franks B (2012) Between Anarchism and Marxism: the beginnings and ends of the schism.... Journal of Political Ideologies 17(2): 207-227.

Glassman J (2006) Primitive accumulation, accumulation by dispossession, accumulation by 'extra-economic' means. Progress in Human Geography 30(5): 608-625.

Gordon U (2008) Anarchy Alive! Anti-authoritarian Politics from Practice to Theory. London: Pluto Press.

Graeber D (2007) The New Anarchists. New Left Review I(13): 61-73

Graeber D (2012) Occupy Wall Street's Anarchist Roots. In Byrne J (ed.) The occupy Handbook. New York, NY: Back Bay Books.

Graeber D (2013) The Democracy Project: A History, A Crisis, A Movement. London: Penguin. Hardt M, Negri A (2006) Multitude. London: Penguin.

Harford T (2008) The Logic of Life: The Rational Economics of an Irrational World. New York, NY: Random House.

Harvey D (2007) A Brief History of Neoliberalism. Oxford: Oxford University Press.

Holloway J (2005) Change the World Without Taking Power. Capital \& Class 29(1): 39-42.

Holloway J (2010) Change the World Without Taking Power: The Meaning of Revolution Today. London: Pluto Press. 
Jameson F (1989) The Political Unconscious: Narrative as a Socially Symbolic Act. London: Routledge.

Jameson F (2009) Valences of the Dialectic. London: Verso.

Jameson F (2011) Representing Capital: A Commentary on Volume One. London: Verso.

Jun N (2010) Anarchist Philosophy: Past, Problems and Prospects. In Franks B, Wilson M (eds.) Anarchism and Moral Philosophy. Basingstoke: Palgrave Macmillan.

Jun N (2012) Anarchism and Political Modernity. London: Continuum.

Kinna R (2009) Anarchism: A Beginner's Guide. Oxford: Oneworld.

Kinna R, Prichard A (2012) Introduction. In Prichard A, Kinna R, Pinta S, Berry D (eds.)

Libertarian Socialism: Politics in Black and Red. Basingstoke: Palgrave Macmillan.

Lapavitsas C et al. (2012) Crisis in the Eurozone. London: Verso.

Lapavitsas C (2013) Profiting Without Producing: How Finance Exploits Us All. London: Verso.

Levitt SD, Dubner SJ (2006) Freakonomics: A Rogue Economist Explores the Hidden Side of Everything. London: Penguin Books.

Marx K (1988) Political Indifferentism. In Marx K, Engels F Collected Works, vol. 23. London: Lawrence and Wishart.

Marx K, Engels F (1956) Selected Correspondence. Moscow: Foreign Languages Publishing House

Marx K, Engels F (1976) The German Ideology. In Marx K, Engels F Collected Works Volume 5. London: Lawrence and Wishart.

May T (2013) Friendship as Resistance. In Blumenfled J, Bottici C, Critchley S (eds.) The Anarchist Turn. London: Pluto Press.

Mirokowski P (2013) Never Let a Serious Crisis Go to Waste: How Neoliberalism Survived the Financial Meltdown. London: Verso.

Munck R (2005) Neoliberalism and Politics, and the Politics of Neoliberalism. In Saad-Filho A, Johnston D (eds.) Neoliberalism: A Critical Reader. London: Pluto Press.

Negri A (1989) The Politics of Subversion: A Manifesto for the Twenty-First Century, trans. Newell J. Cambridge: Polity Press.

Newman S (2010) The Politics of Postanarchism. Edinburgh: Edinburgh University Press. 
Price W (2013) The Value of Radical Theory: An Anarchist Introduction to Marx's Critique of Political Economy. Oakland, CA: AK Press.

Rancière J (1999) Disagreement: Politics and Philosophy, trans. Rose J. Minneapolis, MN: University of Minnesota Press.

Read J (2009) A Genealogy of Homo-Economicus: Neoliberalism and the Production of Subjectivity. Foucault Studies 6: 25-36.

Sandel MJ (2012) What Money Can't Buy: The Moral Limits of Markets. London: Allen Lane

Schmidt M, Van der Walt L (2009) Black Flame: The Revolutionary Class Politics of Anarchism and Syndicalism, Counter-Power Vol. 1. Oakland, CA: AK Press.

Shannon D, Nocella II AJ, Asimakopolous J (2012) Anarchist Economics: A Holistic View. In Shannon D, Nocella II AJ, Asimakopolous J (eds.) The Accumulation of Freedom: Writings on Anarchist Economics. Oakland, CA: AK Press.

Taylor B (2013) From alterglobalization to Occupy Wall Street: Neoanarchism and the new spirit of the left. City: analysis of urban trends, culture, theory, policy, action 17(6):729-747.

Thomas P (2010) Karl Marx and the Anarchists. Abingdon: Routledge.

Van der Walt $L$ (2011) Counterpower, participatory democracy, revolutionary defence: debating Black Flame, revolutionary anarchism and historical Marxism. International Socialism Journal 130 http://www.isj.org.uk/?id=729, accessed 7 January 2015.

Wilde L (ed.) (2001) Marxism's Ethical Thinkers: From Kautsky to Heller. Basingstoke: Palgrave.

\section{Acknowledgments}

An early version of this paper was presented at the Political Studies Association Annual Conference in Manchester in April 2014; for their comments and suggestions, I am grateful to those in attendance and to the three anonymous reviewers. 